\section{Ks. Paweł Podeszwa}

UAM Poznań

DOI: http://dx.doi.org/10.12775/BPTh.2014.002

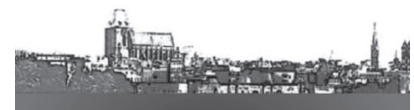

Biblica

et

Patristica

Thoruniensia

7 (2014) $1 \quad$ ISSN 1689-5150

\title{
Droga wiary apostoła Piotra w świetle zapowiedzi zdrady (Łk 22,31-34) oraz wyparcia się Jezusa (Łk 22,54b-62)
}

\section{Apostle Peter's way of faith in the light of the announcement of betrayal (Luke 22:31-34) and denial of Jesus (Luke 22:54b-62)}

Słowa kluczowe: Piotr; wiara; zdrada; zaparcie; modlitwa Jezusa; przebaczenie; nawrócenie.

Key words: Peter; faith; betrayal; denial; Jesus' prayer; foregiveness; conversion.

Streszczenie. Jedną z najbardziej znanych postaci Nowego Testamentu, obok samego Jezusa, jest apostoł Piotr. Powołany nad jeziorem Genezaret szedł wiernie za Chrystusem, odkrywając stopniowo tożsamość Jezusa, ale także prawdę o samym sobie, przygotowując się w ten sposób do misji głoszenia Ewangelii. Była to dla niego prawdziwa droga wiary.

W artykule omówione zostało jedno z najbardziej znaczących wydarzeń w historii Piotra. Chodzi o moment zaparcia się Mistrza tuż przed męką Jezusa. Proponowana refleksja opiera się na opowiadaniu o tym wydarzeniu w redakcji Łukasza, który doskonale ilustruje drogę wiary apostoła Piotra jako drogę koniecznego przejścia przez doświadczenie własnej słabości i niewystarczalności, co ostatecznie prowadzi do zwrócenia się (nawrócenia) ku mocy Kogoś Innego.

Artykuł składa się z trzech części. W pierwszej analizie została poddana zapowiedź zdrady Piotra, wygłoszona przez Jezusa w Wieczerniku (Łk 22,31-34), zawierająca elementy, których brakuje u pozostałych ewangelistów: naleganie szatana, aby doświadczyć uczniów (22,31), modlitwa Jezusa za Piotra, aby nie ustała jego wiara oraz proroctwo-obietnica, że kiedy Piotr się nawróci, będzie umacniał braci w wierze $(22,32)$. Druga część poświęcona została samemu wydarzenia zaparcia się Jezusa przez Piotra na dziedzińcu domu arcykapłana (Łk 22,45b-62), gdzie szczególną wagę odgrywa spojrzenie Chrystusa na Piotra (Łk 22,61). Ostatnia część o charakterze podsumowującym w świetle doświadczenia Piotra ma uświadomić czytelnikom konieczność drogi wiary, która wiedzie od wiary niewłaściwej opartej na własnej wierności do tej prawdziwej, budowanej na wierności i mocy Chrystusa. 
Abstract. One of the best known events in Peter's life are his three acts of denial of Jesus. The denial is referred to in all four Gospels (Matthew 26:58.69-75; Mark 14:54.66-72; Luke 22:54-62; John 18:15-27). What happened in the courtyard of the high priest's palace had been foretold by Jesus himself, though the accounts pertaining to this event given by the Evangelists are slightly different from each other, particularly in terms of the context and time of Jesus' announcement. According to Matthew and Mark the announcement was made after the Last Supper on the way to Getsemani (Matthew 26:31-35; Mark 14:27-31), whereas according to Luke and John it happened during the Last Supper as part of Jesus' farewell address (Luke 22:31-34; John 13:36-38). The subject of our deliberations is the account given by Luke the Evangelist, which illustrates perfectly well Apostle Peter's way of faith as the necessary act of experiencing one's own weakness and insufficiency, which results in turning oneself (converting) to the power of Somebody else. Moreover, Luke's version contains new essential elements which the other Evangelists are missing: Satan insisting on afflicting the disciples (22:31), Jesus praying for Peter that his faith would not fail and the prophecy - a promise that when Peter is converted, he shall strenghten his brothers (22:32).

In light of the analyzed texts, the way of faith does not always bring one from nonbelief to faith. Sometimes it is necessary to embark upon the way which is harder and more demanding, the way which takes one from improper, false faith to the one which is proper and true. Peter's way of faith mirrored the latter. First, he put unconditional trust into himself. He relied on his faithfulness, which he declared openly, spontaneously and readily. He was ready to go with Jesus to prison and to death (22:33). Jesus knew that in order to cleanse Peter's faith, it needed to be shaken and go through a critical period. Jesus approved of such a situation in order to put Peter's faith to test. This approval, however, from the very beginning, had been ingrained with assurance and a promise that Peter's faith, even though put to test, shall not fail completely (22:32). One can say that Jesus, through experiencing three acts of denial, allowed the destruction of Peter's improper and false faith, which was based on Peter being convinced of his power and faithfulness. Peter then was brought onto the way of faith, which was the way of cleansing, conversion and strengthening in genuine faith based on Jesus' forgiving love (22:61-62).

$\mathrm{O}$ jciec Święty Franciszek w swojej encyklice o wierze - Lumen fidei stwier$\mathrm{dza}$, że „wiara otwiera nam drogę i towarzyszy nam na przestrzeni dziejów. Dlatego jeśli chcemy zrozumieć, czym jest wiara, powinniśmy opowiedzieć jej historię, drogę ludzi wierzących"1. W niniejszej refleksji mamy zamiar „opowiedzieć drogę" apostoła Piotra, a szczególnie jedno z wydarzeń jego życia, które miało istotny wpływ na kształtowanie się jego wiary oraz posługę pasterską umacniania braci w wierze i miłości.

1 Franciszek, Lumen fidei, s. 13 (n. 8). 
Osoba Szymona Piotra jest jedną z najbardziej znanych postaci Nowego Testamentu, obok samego Jezusa i Pawła z Tarsu i - jak słusznie twierdzi J. Gnilka - „obok Pawła jest on tym z Apostołów, którego imię i dzieło miało w historii największe oddziaływanie"2. Jego droga za Jezusem, a więc droga wiary, wiodła od Jeziora Galilejskiego, gdzie usłyszał Jezusowe „Pójdź za Mną” (Mk 1,16-17) przez Cezareę Filipową aż po Jerozolimę, a potem jako głosiciela Ewangelii do Rzymu aż po męczeństwo w stolicy cesarstwa. Znamy dobrze poszczególne etapy tej niełatwej drogi Piotra za Jezusem i razem z Nim, drogi wymagającej, która stopniowo i konsekwentnie kształtowała Piotra w duchu Ewangelii.

Jednym z najbardziej znanych wątków (epizodów) z życia Piotra jest wydarzenie w Jerozolimie tuż przed śmiercią Jezusa. Chodzi oczywiście o trzykrotne zaparcie się Jezusa przez Piotra. Wspominają o nim wszyscy ewangeliści (Mt 26,58.69-75; Mk 14,54.66-72; Łk 22,54-62; J 18,15-27). To, co wydarzyło się na dziedzińcu pałacu arcykapłańskiego, zostało zapowiedziane przez samego Jezusa, choć tutaj relacje poszczególnych ewangelistów różnią się nieco między sobą, zwłaszcza jeśli chodzi o kontekst i czas Jezusowej zapowiedzi. Według Mateusza i Marka miała ona miejsce po Ostatniej Wieczerzy w drodze do Getsemani (Mt 26,31-35; Mk 14,27-31), natomiast według Łukasza i Jana jeszcze podczas Ostatniej Wieczerzy w ramach mowy pożegnalnej Jezusa (Łk 22,31-34; J 13,36-38). W naszych rozważaniach zajmiemy się zapisem Łukaszowym ${ }^{3}$, doskonale ilustrującym drogę wiary apostoła Piotra jako drogę koniecznego przejścia przez doświadczenie własnej słabości i niewystarczalności, co prowadzi do zwrócenia się (nawrócenia) ku mocy Kogoś Innego. Ponadto wersja Łukaszowa zawiera w sobie istotne nowe elementy, których brakuje u pozostałych ewangelistów: naleganie szatana, aby doświadczyć uczniów (22,31), modlitwa Jezusa za Piotra, aby nie ustała jego wiara oraz proroctwo - obietnica, że kiedy Piotr się nawróci, będzie umacniał braci w wierze $(22,32)$.

\section{Zapowiedź zaparcia się Piotra (tk 22,31-34)}

Jak już zostało to zasygnalizowane, w Ewangelii według św. Łukasza Jezusowa zapowiedź zaparcia się Piotra została umieszczona w kontekście mowy

2 J. Gnilka, Piotr, s. 5.

3 Trudno jednoznacznie określić pochodzenie tej tradycji. Często przypisuje się ją Łukaszowi, który miałby ją stworzyć z samodzielnych słów i przekazów, jakie były zachowywane we wspólnocie popaschalnej. Jednak cały tekst odznacza się spójnością, co pozwala go traktować jako jednolity opis wydarzenia, zob. B. Maggioni, Ewangeliczne opowieści, s. $200-201$. 
pożegnalnej wygłoszonej przez Jezusa jeszcze w Wieczerniku w czasie trwania Ostatniej Wieczerzy. Po ustanowieniu Eucharystii $(22,14-21)$ i ujawnieniu zdrajcy $(22,22-23)$ uczniowie spierali się między sobą, kto jest najważniejszy z nich $(22,24)^{4}$, a Jezus w odpowiedzi udzielił im pouczeń o konieczności pokory i ducha służby $(22,25-27)$ oraz przekazał im władzę królowania $(22,28-30)$. Kolejną jednostkę literacką stanowią właśnie słowa skierowane do Piotra (22,31-34), które są przedmiotem naszej analizy.

Jezus zwraca się do apostoła, używając podwójnego wołacza „Szymonie, Szymonie" (Si,mwn Si,mwn). Biorąc pod uwagę tradycję biblijną, podwójne użycie imienia służy podkreśleniu znaczenia chwili oraz doniosłości zadania, jakie przywoływana osoba będzie miała do spełnienia ( $\operatorname{Rdz} 22,1 ; \mathrm{Wj} 3,4$; $1 \mathrm{Sm} \mathrm{3,10).} \mathrm{Ewangelista} \mathrm{naśladuje} \mathrm{tę} \mathrm{formę} \mathrm{starotestamentową} \mathrm{(podobnie} \mathrm{w} \mathrm{Łk}$ $10,41 ; 13,34 ; \mathrm{Dz} 9,4 ; 22,7 ; 26,14)$ dla podkreślenia uroczystego tonu wypowiedzi Jezusa oraz faktu, że owa zapowiedź dotyczy w pierwszym rzędzie samego Piotra, choć obecni są pozostali apostołowie ${ }^{5}$. Wskazuje to także na szczególną rolę apostoła we wspólnocie pierwotnego Kościoła ${ }^{6}$.

Następnie słowa Jezusa opisują działanie szatana: „oto szatan wymógł, żeby

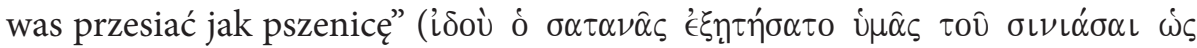

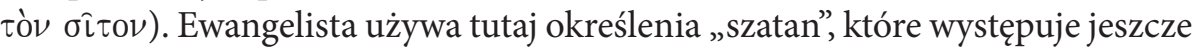
w 10,$18 ; 11,18 ; 13,16 ; 22,3$. Choć został już pokonany $(10,18$ : szatan spadający $\mathrm{z}$ nieba jak błyskawica), to jednak nadal może działać. Jak przed chwilą wszedł w Judasza (22,3), o czym nie wie Piotr, tej samej nocy zaatakuje Piotra. To ten sam szatan, który kusił na pustyni Jezusa $(4,1-2)$ i odstąpił aż do czasu $(2,13)$. Teraz powrócił, aby zaatakować uczniów Jezusa.

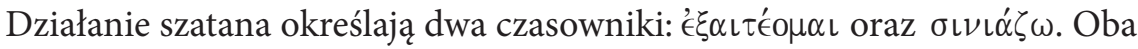
czasowniki stanowią hapax legomena w Nowym Testamencie. Pierwszy wyraża idę nacisku, domagania się wydania kogoś, usilnego proszenia i nalegania. Czasownik został użyty w aoryście, co wskazuje na to, że szatan osiągnął zamierzony cel. Jak słusznie zauważa bp Kiernikowski, „trzeba więc tutaj rozumieć ten czasownik nie w znaczeniu «domagał się, ale mu się to nie udało», ale raczej bliżej w znaczeniu «wymógł to» - czyli osiągnął to przez swoje usilne domaga-

4 Zdaniem K. Wonsa, Ty wiesz, s. 255 zachowanie uczniów Jezusa podczas Wieczerzy i toczący się spór świadczą, że „nie tkwią w rzeczywistości, nie uczą się od Jezusa, ale polegają na własnej opinii. Są przywiązani do swoich wyimaginowanych projektów, które nie mają nic wspólnego z życiem ucznia Jezusa. Piotr jako lider wydaje się zawodzić najbardziej".

Zob. Z. Kiernikowski, Posługa Piotra, s. 87-88; Fr. Mickiewicz, Ewangelia, s. 463.

6 Zdaniem H. Langkammera, Rola Piotra, s. 22 fragment Łk 22,31-38 należy zaliczyć do „klasycznych tekstów prymacjalnych” obok Mt 16,17-19 oraz J 21,15-19. 
nie się tego. Nie było to, co prawda w jego władzy, ale zostało mu to udostępnione"7. W działaniu szatana, który domaga się od Jezusa możliwości działania na Jego uczniów można widzieć nawiązanie do Hi 1-2, gdzie szatan domaga się od Boga, by pozwolił mu poddać próbie wiarę i ufność Hioba. Wiemy, że szatan uzyskał taką zgodę ze strony Boga $(\mathrm{Hi}$ 1,12). Podobnie jak w historii Hioba, tak i teraz szatan może doświadczyć uczniów Jezusa, uzyskuje takie przyzwolenie, może działać, aby osiągnąć zamierzony sukces, który jednak w końcowym rezultacie okaże się jego wielką porażką.

Na czym zależy szatanowi i o co udało mu się wymóc na Jezusie? „Aby was przesiać jak pszenicę". Działanie szatana odnosi się nie tylko do Piotra, ale do wszystkich apostołów (ìnâs). Szatan domaga się od Jezusa możliwości doświadczenia wspólnoty, która ma być „przesiana” ( $\sigma \iota \nu \iota \alpha ́ \sigma \alpha \iota)$ jak pszenica. Użyty czasownik nie tylko wskazuje na przesiania w celu oczyszczenia plew od ziarna pszenicznego, ale „wyraża także, a tutaj prawdopodobnie przede wszystkim: «wstrząśnięcie», a więc wzburzenie, rozbicie czy rozdzielenie właśnie przez jakąśs gwałtowną akcję (zob. Am 9,9). Chodzi więc nie tyle o końcowy efekt przesiania dla oddzielenia ziarna od plew czy piasku, ale raczej o sam moment wstrząsu, zburzenia, zamętu, co naturalnie nie wyklucza końcowego efektu oddzielenia. Zmierza to do destabilizacji jedności, powiązań, relacji zaufania i wierności. To się okaże szczególnie w wydarzeniach męki. Uczniowie wobec krzyża ulegną zamętowi, rozproszeniu"8.

Czy odpowiedzią Jezusa jest zgoda na działanie szatana? Otóż Jezus zapew-

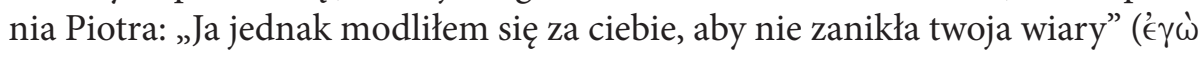

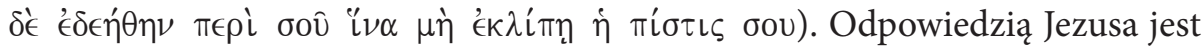
przede wszystkim modlitwa, która ma swój ściśle określony cel: chodzi o to, aby nie ustała wiara (wierność ${ }^{9}$ ) Piotra ${ }^{10}$. Użyty czasownik $\epsilon \kappa \lambda \in i m \omega$ „opisuje proces zmniejszania się czegoś aż do jego zaniku"11, a zastosowana konstrukcja gramatyczna $(\mu \eta,+$ coniunctivus $=$ tryb łączący) nie wyraża niedopuszczenia zaistnienia procesu zanikania w naszym przypadku wiary Piotra, ale zatrzymanie tego procesu, aby nie doszedł do końca ${ }^{12}$. Zatem „ze słów Jezusa można

\footnotetext{
7 Z. Kiernikowski, Posługa Piotra, s. 89.

8 Ibidem, s. 90. Podobnie S. Cipriani, Św. Piotr Apostoł, s. 78-79.

9 Zob. J. Gnilka, Piotr, s. 67.

10 K. Wons, Ty wiesz, s. 257: „Jezus prosił Pjca, aby nie ustała (eklipe) jego wiara, nie zanikła jak księżyc podczas zaćmienia i nie zamieniła się w kompletną ciemność niewiary”.

11 Fr. Mickiewicz, Ewangelia, s. 464.

12 Zob. Z. Kiernikowski, Postuga Piotra, s. 93.
} 
wnioskować, że w wyniku ataku szatana wiara Piotra zostanie zachwiana i poddana ciężkiej próbie, ale dzięki interwencji Mistrza nie zaniknie całkowicie"13.

Uwagę zwraca także fakt, że mimo iż działanie szatana dotyczy wszystkich apostołów, to jednak modlitwa Jezusa odnosi się do wiary apostoła Piotra

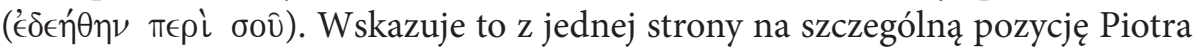
we wspólnocie, ale przede wszystkim na prawdę, że wiara innych zależeć będzie w zasadniczy sposób od wiary apostoła Piotra. Potwierdzeniem tego są dalsze słowa Jezusa, które niosą w sobie jednocześnie proroctwo i obietnicę: „A ty, kiedyś nawróciwszy się [gdy kiedyś nawrócisz się], utwierdzaj swoich braci”

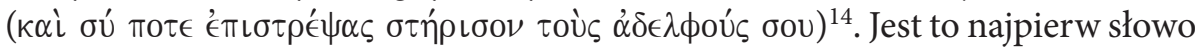
proroctwa, które odnosi się do słabości Piotra i potrzeby jego nawrócenia, na

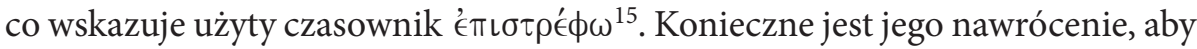
mógł wykonywać powierzone mu zadanie bycia skałą twardą i solidną, której nie poruszy żadna nawałnica, oraz utwierdzania braci w wierze. Konstrukcja zdania jednoznacznie wskazuje, że Jezus nie tylko zapowiada konieczność nawrócenia Piotra, ale także je obiecuje i to w niedalekiej przyszłości, bo tylko wtedy Piotr będzie mógł wypełnić swoją misję. Przyszłe zadanie apostoła jest wyrażone czasownikiem $\sigma \tau \eta \rho i \zeta \omega$, który zwłaszcza w Dziejach Apostolskich (Dz 14,22; 15,32.41; 18,23 ${ }^{16}$ ) oznacza zachętę, szczególnie w chwilach przeciwności. Według S. Ciprianiego, „Z całego kontekstu, który odnosi się do nieodległej próby, jaką będzie męka Jezusa, można wywnioskować, że zadaniem Piotra, którym przecież wstrząsną te wydarzenia, ma być «umacnianie» innych, żeby nawet jeśli zdradzą, nie popadli w niewiarę czy rozpacz: objawienie się Zbawiciela i jego własna skrucha, ułatwią Piotrowi tę rolę «umacniającego» wiarę swoich "braci»"17. Zobaczymy w dalszej części naszych rozważań, że zadanie Piotra będzie przede wszystkim polegało na utwierdzaniu braci, to jest innych apostołów (kontekst bezpośredni) oraz przyszłych wierzących (kontekst dalszy) we właściwej (prawdziwej ${ }^{18}$ ) wierze, to znaczy opartej nie na przekonaniu o własnej wierności i sile, ale całkowitym zdaniu się na Jezusa.

13 Fr. Mickiewicz, Ewangelia, s. 464.

14 Na temat problematyki tłumaczenia 22,32b zob. P. Oktaba, Modlitwa Jezusa, s. 130-133 .

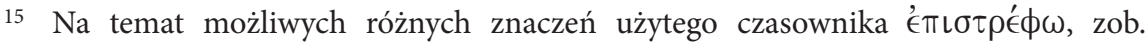
Z. Kiernikowski, Posługa Piotra, s. 94-95.

16 Tutaj występuje jednak forma złożona: $€$ $\pi \iota \sigma \tau \eta \hat{\imath} \zeta \omega$.

17 S. Cipriani, Św. Piotr, s. 80.

18 R. Brandstaetter, Jezus $z$ Nazarethu, s. 459, parafrazuje wypowiedź Jezusa w następujący sposób: „Kefasie, Kefasie, dopiero gdy się nauczysz prawdziwie wierzyć, będziesz utwierdzał braci swoich". 
Podsumowując tę część analiz, można stwierdzić, że Jezus przepowiada Piotrowi swoistego rodzaju drogę wiary, która będzie najpierw wiodła przez doświadczenie kryzysu wierności i obnaży słabość apostoła, co głęboko nim wstrząśnie i spowoduje, że jego więź z Jezusem i wspólnotą zostanie poważnie osłabiona, będzie bliska całkowitemu zaniknięciu, jednak nie zostanie całkowicie zerwana. Piotr musi przejść przez to bolesne, ale jednocześnie konieczne doświadczenie, aby się nawrócić i niejako powrócić w nowy sposób do Jezusa i do wspólnoty, aby móc utwierdzać braci. Słowa Jezusa zawierają oczywistą obietnicę, że takie przejście jest możliwe i rzeczywiście dokona się w życiu apostoła.

Teraz możemy postawić kolejne pytania: dlaczego Piotr ma się nawrócić? o jakim nawróceniu mówi Jezus? skąd apostoł ma powrócić do Jezusa i wspólnoty?

Odpowiedź przynoszą kolejne wersety. Kiedy Jezus zapowiada apostołowi doświadczenie, które go czeka, a także nawrócenie i przyszłą misję, reakcja Piotra jest natychmiastowa i polega na deklaracji absolutnej wierności ze strony apostoła, który jest gotów iść za Jezusem do więzienia, a nawet na śmierć $(22,33)$. Jak trafnie komentuje ks. Mickiewicz: „Piotr zdaje się tutaj przedstawiać swemu Panu program dobrego chrześcijanina, odznaczającego się heroiczną cnotą wierności w obliczu dotkliwych prześladowań, jednakże na tym etapie jego rozwoju duchowego jego zapewnienie wypływa bardziej z porywczego charakteru i zbytniej pewności siebie aniżeli z rzeczywistej stanowczości i niezachwianej gotowości na męczeństwo. Jak się okaże, Piotr będzie musiał przejść jeszcze długą drogę przemiany i duchowego umocnienia, aby jego program stał się realistyczny i możliwy do wykonania"19.

W odpowiedzi Piotr słyszy gorzkie, ale prawdziwe słowa Jezusa, które zapowiadają bliską zdradę: „Mówię ci, Piotrze, dziś, nim kogut zapieje, trzy razy wyprzesz się tego, że Mnie znasz" (22,34). Na uwagę zasługuje mocne podkreślenie bliskości czasowej zapowiadanego wydarzenia (dziś), co jeszcze bardziej uwypukla kontrast między deklaracją Piotra o gotowości więzienia i śmierci dla Jezusa, a postawą zdrady i wyparcia się znajomości Jezusa. Warto zwrócić także uwagę, że w stosunku do Mt 26,34 i Mk 14,30, wydaje się, że Łukasz nieco łagodzi zapowiedź samego wyparcia się Jezusa przez Piotra, gdyż dotyczy ona znajomości z Jezusem (Mt 26,34: „trzy razy się Mnie wyprzesz”; Mk 14,30: „trzy razy się Mnie wyprzesz”; Łk 22,34: „trzy razy wyprzesz się tego, że Mnie znasz”). Ponadto Jezus zwraca się do apostoła imieniem „Piotr”, które sam mu nadał $(6,14)$. Biorąc po uwagę fakt, że wcześniej Jezus zwracał się do apostoła imieniem „Szymon” (22,31), być może mamy tutaj oczywiste przypomnienie

19 Fr. Mickiewicz, Ewangelia, s. 465. 
roli apostoła jako „Skały” albo „lekką ironię”, gdyż „Piotr, czyli Skała, w rzeczywistości jest jeszcze skałą chwiejną i niepewną, ponieważ zbytnio polega na sobie i swych ludzkich siłach. Ale Jezus nie odwołuje nadanego mu drugiego imienia, gdyż w przyszłości, dzięki łasce Bożej, stanie się on rzeczywiście fundamentem Kościoła i wzorem wierności swemu Panu"20.

\section{Zaparcie się Piotra $(22,54 b-62)$}

Wszyscy ewangeliści opowiadają o zaparciu się Piotra (Mt 26,58-75; Mk 14,54-72; Łk 22,54-62; J 18,15-18.25-27). Co do miejsca wydarzenia są zgodni: dziedziniec pałacu arcykapłańskiego (Mt 26,58; Mk 14,54; Łk 22,55; J 18,15-16). Różnica polega jednak na samym momencie zaparcia się Piotra. Według Mt, Mk i J miało ono miejsce w czasie przesłuchania Jezusa przez arcykapłana i Wysoką Radę, podczas gdy Łukasz opowiada zaparcie się Piotra i jego nawrócenie zaszło przed rozpoczęciem procesu żydowskiego. Zdaniem niektórych komentatorów ma to znaczenie dla Łukasza, gdyż w ten sposób „w czasie procesu Jezusa Piotr jest już po stronie Jezusa jako nawrócony"21, jako ten, który dokonał właściwego wyboru w odróżnieniu od przywódców ludu Starego Testamentu, którzy odrzucą Jezusa (22,66-71).

Według trzeciej Ewangelii mamy zatem następujący ciąg zdarzeń: po pojmaniu Jezusa na Górze Oliwnej (22,47-53) „pochwycili Go, zabrali i zaprowadzili do domu najwyższego kapłana" (22,54a). Ewangelista wspomina, że towarzyszył Mu tylko Piotr, który „szedł za Nim z daleka" (22,54b). Następnie ma miejsce zaparcie się Jezusa przez Piotra (22,55-60). Nie wiadomo dokładnie, gdzie w tym czasie znajdował się Jezus. Ewangelista nie precyzuje tego dokładnie, ale kontekst (zwłaszcza 22,61) pozwala się domyślać, że Jezus był także na dziedzińcu (albo w domu arcykapłana) i w ten sposób stał się niejako naocznym „świadkiem” całego wydarzenia. Dopiero po spotkaniu Jezusa z Piotrem $(22,61)$ i jego nawróceniu $(22,62)$, Jezus został wyszydzony $(22,63-65)$ i stanął przed Wysoką Radą (22,66-71).

Po aresztowaniu Jezusa w Getsemani apostoł towarzyszy wiernie Jezusowi.

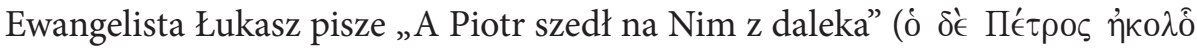
v́$\theta \in \iota$ $\mu \alpha \kappa \rho o ́ \theta \in \nu)$. Ten sam czasownik pojawił się w opowiadaniu o powołaniu Piotra, Jakuba i Jana, kiedy „zostawili wszystko i poszli za Nim” $(5,11)$. Można zatem powiedzieć, że Piotr wypełnia wiernie zadanie ucznia, idzie ciągle za Jezusem, mimo trudnej sytuacji, w której obaj się znaleźli. Dopowiedzenie

20 Ibidem, s. 465-466.

21 Z. Kiernikowski, Posługa Piotra, s. 96. 


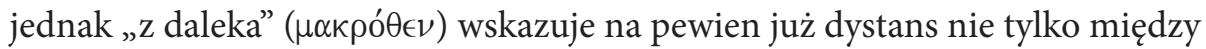
Piotrem a tymi, którzy pojmali Jezusa, ale być może Łukasz myśli już o stopniowym oddalaniu się Piotra od samego Jezusa i wspólnoty (szedł sam!).

Kiedy apostoł znalazł się na dziedzińcu pałacu arcykapłana (22,55), rozpalono ognisko, Piotr znalazł się blisko ognia. Gdy jego blask rozświetlił mroki, nocy jedna ze służących rozpoznała w Piotrze towarzysza Jezusa i wskazując na

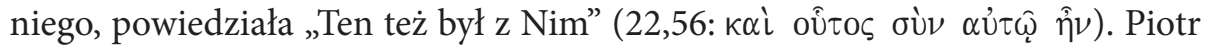
natychmiast stanowczo zaprzeczył: „Kobieto, nie znam Go” (22,57: oủk oî́ $\alpha$

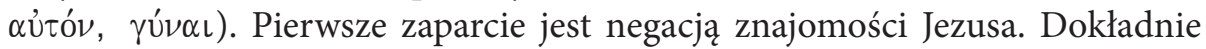
wypełnia się zapowiedź Jezusa, że Piotr wyprze się, że zna Jezusa. Apostoł Piotr w bardzo stanowczych słowach neguje swoją relację z Jezusem. On Go nie zna. Nie ma z nim nic wspólnego. Zadaniem ucznia idącego za Jezusem było rozpoznać Jego tożsamość jako Mesjasza i Syna Bożego, a Piotr całkowicie odrzuca jakąkolwiek znajomość już nie tylko Jezusa, ale także z Jezusem.

Kolejny dialog ma miejsce nieco później, kiedy ktoś inny stwierdził, że Piotr

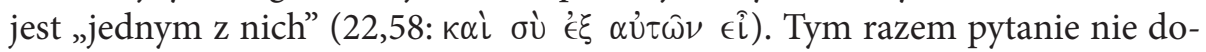
tyczy tylko i wyłącznie relacji Piotra do Jezusa, ale do wspólnoty Jego uczniów. Piotr jest postrzegany jako ,jeden z nich”, to znaczy towarzyszy Jezusa. Apostoł wypiera się przynależności do grona uczniów Jezusa: „człowieku, nie jestem”

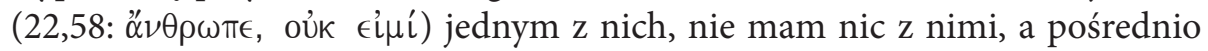
z Nim, wspólnego, nic nas nie łączy, nie identyfikuję się z nimi w żadnej mierze. Kolejne kłamstwo Piotra, które tym razem dotyczy jego relacji do braci. Ten, który ma utwierdzać ich wiarę, wypiera się jakiegokolwiek związku z nimi. Tragicznie wymowne jest jego wyznanie „Nie jestem”. Jakby zdawał się mówić: „Jeśli nie jestem $\mathrm{z}$ Jezusem, jeśli nie jestem z braćmi, to tak jakbym nie istniał - nie jestem”. Bez nich traci tożsamość Kefasa. Jakby zaprzeczał swemu istnieniu ${ }^{22}$.

Po upływie około godziny jeszcze inny stanowczo twierdził, że Piotr „z

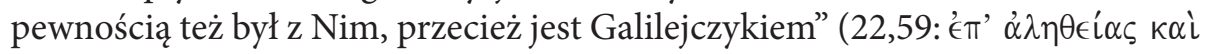

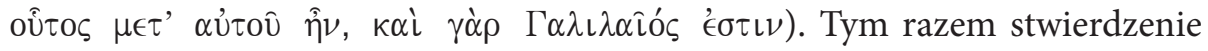
kogoś z dziedzińca arcykapłana dotyczy znowu w pierwszym rzędzie relacji Piotra do samego Jezusa („był z Nim”). Potwierdzeniem przekonania o przynależności Piotra do Jezusa miało być jego pochodzenie z Galilei, które mógł zdradzać galilejski akcent apostoła, bez trudu rozpoznawalny w Jerozolimie ${ }^{23}$.

22 K. Wons, Ty wiesz, s. 269.

23 Mateusz wyjaśnia, w jaki sposób rozpoznano Piotra jako Galilejczyka, a co za tym idzie, jako należącego do ruchu Jezusowego: „Nawet twoja mowa cię zdradza” (26,73). Ludność Galilei miała charakterystyczną, odróżniającą ich od innych wymowę aramejskiego. Polegała ona zwłaszcza na niedokładnym wymawianiu głosek gardłowych. Mieszano między innymi wymowę ajin z aleph, zob. J. Gnilka, Piotr, s. 78. 
Podobnie jak poprzednio, reakcja Piotra jest jednoznaczna i nader stanowcza:

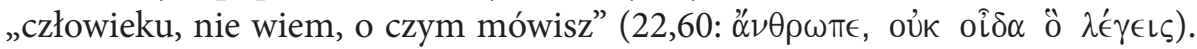
Piotr konsekwentnie nie chce być w żaden sposób łączony ani $\mathrm{z}$ Jezusem ani z ewentualnym gronem Jego towarzyszy, pochodzących głównie z Galilei. Trzecie zaprzeczenie nie odnosi się wyłącznie do relacji Piotra do Jezusa i Jego uczniów, ale w pewien sposób Piotr neguje także to kim sam jest, kiedy wypiera się swojej ojczyzny, domu, galilejskiego pochodzenia, wielu wspomnień, związanych $\mathrm{z}$ tamtą krainą powołania i wyboru, jednym słowem zapiera się swojej tożsamości. Piotr Skała pęknął, „zaczyna wątpić we wszystko. Już nie tylko wątpi w to, czy Jezus i wspólnota mają dla niego jakieś znaczenie. Wątpi także w siebie, we wszystko, kim był, wątpi w swoją tożsamość" ${ }^{24}$.

Piotr nie skończył jeszcze mówić, kiedy „kogut zapiał”. Tylko Łukasz wspomina w tym miejscu obecność samego Chrystusa i Jego reakcję: „Pan odwrócił

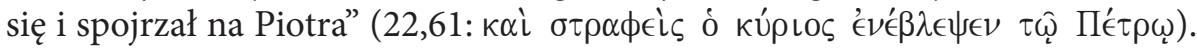
Ewangelista nie mówi tego wprost, ale można mieć wrażenie, że Jezus cały przez czas był świadkiem całego wydarzenia i słyszał dialogi Piotra. To jeszcze bardziej podkreśla dramatyzm całej sytuacji: Piotr wyparł się Mistrza, będąc blisko Niego! Jak pisze ks. Wons: „Historia Piotra kryje w sobie dramatyczny paradoks: zapiera się on Jezusa, idąc za Jezusem, oddala się, odchodzi od Niego w sytuacji, gdy usiłuje iść za Nim aż do więzienia i na śmierć. Ten paradoks obnaża bolesną konsekwencję jego połowicznych i pozornych decyzji. Widzimy Piotra w głębokim kryzysie wiary, powołania"25.

Jaka jest odpowiedź zdradzonego Pana? Jezus zwraca się do apostoła ( $\left.\sigma \tau \rho \phi \epsilon \epsilon^{\prime} \varsigma\right)$ i obdarza go swoim spojrzeniem (' $\left.\nu^{\prime} \in \beta \lambda \epsilon \psi \epsilon \nu\right)$. Trudno na podstawie tekstu jednoznacznie powiedzieć, jaki charakter miało to spojrzenie Jezusa: wyrzutu, oskarżenia, nagany, rozczarowania, współczucia, przebaczenia. Ewangelista nie precyzuje tego dokładnie, ale spojrzenie Jezusa było potwierdzeniem Jego bliskości mimo zdrady ze strony apostoła, On nie wyparł się swojego ucznia, nie odszedł, nie oddalił się, nie minął go obojętnie. Piotr nadal był dla Niego kimś ważnym, bliskim. Jezus spojrzał na Piotra w najtrudniejszym i najciemniejszym momencie jego życia. Dla Piotra było to z pewnością spojrzenie miłości i wierności Jezusa Pana. Być może przywołało w pamięci inne wydarzenie, kiedy Jezus po raz pierwszy spojrzał na niego (' $\left.\mu \beta \lambda \lambda^{\prime} \epsilon \alpha \varsigma\right)$ i powiedział: „Ty będziesz nazywał się Kefas” (J 1,42).

To spojrzenie Jezusa wystarczyło także, aby Piotr przypomniał sobie słowa Mistrza z Wieczernika, w których zapowiadał trzykrotne zaparcie się Piotra $(22,34)$ i jego zdradę: Przypomniał sobie Piotr słowo Pana, gdy mu powiedział:

24 K. Wons, Ty wiesz, s. 271.

25 Ibidem, s. 261. 
„Dzisiaj, nim kogut zapieje, trzy razy się mnie wyprzesz” (22,61). Być może wtedy Piotr przypomniał sobie jeszcze coś ważniejszego, że Jezus nie tylko przepowiedział słabość i upadek apostoła, ale obiecał mu także, że jego wiara nie ustanie $(22,32)^{26}$. To właśnie ona sprawiła, że „wyszedł na zewnątrz i gorzko

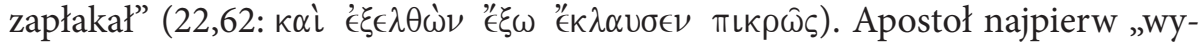
szedł na zewnątrz". W skazuje to na wyjście z miejsca, ze środowiska, które stało się przyczyną upadku i zdrady Jezusa, wspólnoty i siebie samego. Piotr opuścił dziedziniec arcykapłańskiego pałacu. Uświadamiając sobie wielkość słabości, która się objawiła, żałował szczerze i gorzko zapłakał. Jego łzy były wyrazem skruchy i żalu. W ten sposób Piotr odwraca się (nawraca się) od ufności w siebie i poleganiu wyłącznie na sobie, które przecież zawiodły w tak ważnym momencie życia apostoła, a zwraca się (powraca) ku całkowitej ufności Jezusowi i tylko Jemu. Piotr powraca do Jezusa i tym samym do wspólnoty z innymi wierzącymi.

\section{Droga wiary apostoła Piotra}

Omówione wyżej doświadczenie apostoła Piotra uczy nas, że droga wiary nie zawsze prowadzi tylko i wyłącznie od niewiary ku wierze, ale czasami konieczna jest droga trudniejsza i bardziej wymagająca, która wiedzie od niewłaściwej, fałszywej wiary do tej jedynej właściwej i prawdziwej. Kiedy śledzimy losy Piotra opisane w ewangeliach, możemy bez przesady powiedzieć, że był człowiekiem „wielkiej wiary”. Wydawać by się mogło, że jego wierze niczego nie brakowało, że była ona mocna i zdolna, przynajmniej według deklaracji apostoła, pokonywać wszelkie trudności i przeszkody, na które napotykała. A jednak wydarzenia męki i śmierci Jezusa obnażyły prawdziwe oblicze wiary Piotra. Jak pisze bp Kiernikowski «problem Piotra nie polegał na tym, że miał „mało” wiary, lecz na tym, że miał zbyt dużo niewłaściwej wiary, zbyt dużo przekonania o swojej wierności. Jezusowi chodziło o to, by Piotr doświadczył i zrozumiał, że istotna jest nie deklarowana wielkość wiary czy wierności, jak to zdaje się wynikać ze słów Piotra przed zaparciem, lecz pokorne dostrzeżenie i uznanie tego maleńkiego zaczynu w kształtowaniu nowej relacji człowieka - poznającego siebie w świetle jakiegoś kryzysu tożsamości - do Boga. Wówczas człowiek może pojąc wiarę jako czysty i całkowity dar» ${ }^{27}$.

26 Zob. P. Oktaba, Modlitwa Jezusa, s. 132.

27 Z. Kiernikowski, Posługa Piotra, s. 95-96. 
Piotr przeszedł dokładnie taką drogę wiary. Najpierw ufał całkowicie sobie, polegał na swojej wierności, którą deklarował otwarcie, spontanicznie i łatwo. Był gotowy iść z Jezusem do więzienie, a nawet na śmierć. Jezus wiedział, że aby oczyścić wiarę Piotra, potrzebuje ona wstrząsu i kryzysu. Zgodził się na taką sytuację, aby apostoł przeszedł próbę wiary. W tę zgodę Jezusa jednak od samego początku było wpisane zapewnienie i obietnica, że wiara Piotra, choć zostanie wystawiona na próbę, nie zaniknie całkowicie. Można by powiedzieć, że Jezus poprzez doświadczenie, które stało się udziałem apostoła, pozwolił niejako na zniszczenie niewłaściwej (fałszywej) wiary Piotra, która bazowała na przeświadczeniu o możliwościac h własnej mocy i wierności. Piotr został zatem wprowadzony na drogę wiary, która była drogą oczyszczenia, nawrócenia i umocnienia $\mathrm{w}$ wierze prawdziwej.

Droga wiary Piotra wiodła przez doświadczenie własnej słabości, ograniczenia, strachu, które doprowadziły do zdrady Mistrza, wspólnoty Jego uczniów oraz poniekąd siebie samego, kiedy zanegował nawet przynależność do swojej ojczyzny i pochodzenie z Galilei. Piotrowi została jednak dana możliwość poznania własnej słabości, niewystarczalności, niewierności. To była bardzo ważna lekcja, która z jednej strony burzyła wiarę w siebie, wiarę opartą na ludzkich możliwościach, ale dała Piotrowi możliwość oparcia się „na doświadczeniu przebaczającej wierności Boga objawionej w Jezusie w kontekście poznania przez Piotra własnej niewierności”28.

Droga wiary apostoła od opierania się na swojej wierności do budowania na mocy i pewności Jezusa ${ }^{29}$ stała się drogą nawrócenia i powrotu do Jezusa: całkowitego odejścia od siebie, aby w nowy sposób zbliżyć się i przyjść do

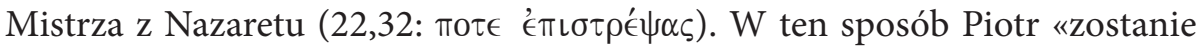
przygotowany do zadania umacniania braci właśnie wówczas, gdy pozna (odkryje i uzna) swoją chwiejność i dlatego będzie mógł odwołać się do wstawienniczej interwencji Jezusa, umożliwiającej mu powrót, nawrócenie. Jego mocą stanie się umiejętność (poznania i podejmowanie decyzji) powrotu do Jezusa. Uznanie swego "grzechu”, to znaczy swego błędu co do własnej wierności, i nawrócenie się właśnie w tej dziedzinie było możliwe dzięki spotkaniu z przebaczającą wiernością Jezusa. Piotr potrzebował tego przeżycia, by odtąd być wiernym w oparciu o to doświadczenie (a nie o swoje przekonanie) i móc umacniać braci. Piotr musiał przeżyć wstrząs, zachwianie się wskutek dopuszczonego przez Boga (i przez Jezusa) działania szatana, podczas którego - dzięki wstawienniczej modlitwie Jezusa - mimo owego krytycznego

28 Ibidem, s. 98.

29 Zob. H. Langkammer, Rola Piotra, s. 23. 
wstrząsu, nie doznał zaniku wiary. Ta wiara została „wypróbowana” i oczyszczona, nie tylko przez wzmocnienie dotychczasowej własnej wiary, lecz przez jej kryzys, aż do granic zaparcia się, by nie być opartym na sobie, lecz odkryć potrzebę oparcia się na słowie Jezusa - na Bogu [...]. Tylko taka wiara może stanowić odniesienie do umacniania braci" ${ }^{\prime 30}$.

Droga wiary, którą przeszedł apostoł Piotr, jest także naszą drogą, polegającą na nieustannym oczyszczaniu i umacniania prawdziwej wiary. Chrystus ciągle modli się i za nas „aby nie ustała nasza wiara”, choć często jest i będzie poddawana koniecznym próbom i wyzwaniom. Pamiętajmy wtedy o Piotrze i jego historii. Pamiętajmy o „człowieku zdolnym do zdrady, ale potrafiącym wyrazić żal o dalej okazywać miłość” ${ }^{1}$. Piotr jest „człowiekiem, którego można obdarzyć zaufaniem! Jest też osobą, która wzbudza sympatię: rodzi się ona z poczucia, że przed każdym z nas jaśnieją promyki nadziei i odkupienia”32.

\section{Bibliografia}

Brandstaetter R., Jezus z Nazarethu, t. III-IV, Kraków 2005.

Cipriani S., Św. Piotr Apostoł, Kraków 2008.

Franciszek, Lumen fidei, Kraków [b.r.w.].

Gnilka J., Piotr i Rzym, Kraków 2002.

Kiernikowski Z., Postuga Piotra (Łk 22,31-32). Przewodniczenie w nawracaniu, w: S. Hałas, P. Włodyga (red.), Pan moja moca i pieśnia (Ps 118,14). Prace dedykowane Księdzu Profesorowi Tadeuszowi Brzegowemu w 65. rocznicę urodzin, Kraków 2006, s. 85-99.

Langkammer H., Rola Piotra w pierwotnym Kościele, w: S. Szymik, H. Ordon (red.), Opoka Kościoła Chrystusowego, Lublin 2004, s. 17-25.

Maggioni B., Ewangeliczne opowieści o Męce Pańskiej, Kraków 2002.

Mickiewicz Fr., Ewangelia wedlug świętego Łukasza, cz. II: rozdziały 12-24, Częstochowa 2012.

Oktaba P., Modlitwa Jezusa i Kościoła za Piotra (Łk 22,31-32), VV 6(2004), s. 129-145. Wons K., Ty wiesz, że Cię kocham, Kraków 2010.

\footnotetext{
Z. Kiernikowski, Posługa Piotra, s. 98.

S. Cipriani, Św. Piotr, s. 84

32 Ibidem.
} 
